\title{
Determination of 25 Low Molecular Weight Carbohydrates in Tobacco by High Performance Ion Chromatography*
}

by

\author{
Marina Cotta Ramusino, Bruno S. Dattilo, Andrea Lucibello \\ and Sergio $G$. Rossi
}

Divisione Ricercbe, Monopoli di Stato

Piaza Mastai 11,00153 Roma, Italy

\section{SUMMARY}

A High Petformance Ion Chromatographic method for the qualitative and quantitative determination of low molecular weight carbohydrates in tobacco leaf is described. The carbohydrates were separated by running isocratic or gradient elutions on columns packed with amino-modified polystyrene divinylbenzene phases, using $0.1 \mathrm{~N} \mathrm{NaOH}$ as eluent. The compounds were detected by a Pulsed Amperometric Detector, after post-column addition of $1 \mathrm{~N} \mathrm{NaOH}$ solution. Twentytwo and twenty-four carbohydrates out of twenty-five were separated by isocratic and gradient elution, respectively. Some mono and disaccharides were identified in tobacco samples by their retention times and some quantitative determinations of glucose, fructose, inositol and saccharose were carried out using different varieties of tobacco.

\section{ZUSAMMENFASSUNG}

Eine Methode zur qualitativen und quantitativen Bestimmung von niedermolekularen Kohlehydraten in

\footnotetext{
* Received: 25th March 1993 - accepred: 4ch Jenuary 1994 Paper presented in part at the CORESTA Symposium, Kallithea (Greece), ocrober $7-11,1990$
}

Tabakblättern durch (Hochleistungs-)Ionenchromatographie wird beschrieben. Die Trennung der Kohlenwasserstoffe erfolgte durch isokratische oder Gradientenelution mittels Säulenchromatographie. Die Säulen waren mit Polystyrendivinylphasen, die mit Aminogruppen modifiziert wurden, gefüllt, wobei $0,1 \mathrm{~N}$ $\mathrm{NaOH}$ als Elutionsmittel diente. Die Detektion der getrennten Verbindungen erfolgte amperometrisch nach Zugabe einer $1 \mathrm{~N} \mathrm{NaOH}$-Lösung. 22 und 24 Kohlehydrate von insgesamt 25 wurden isokratisch beziehungsweise mittels Gradientenelution getrennt. Einige Mono- und Disaccharide wurden durch ihre Retentionszeit aus den Tabakproben identifiziert und einige quantitative Bestimmungen von Glukose, Frukcose, Inositol und Saccharose verschiedener Tabakvarietäten wurden durchgefïhrt.

\section{RESUME}

Ce travail décrit une méthode de chromatographie ionique haute performance utilisée pour l'analyse qualitative et quantitative des hydrates de carbone de faible poids moléculaire contenus dans les feuilles de tabac. Les hydrates de carbone ont été séparés au moyen d'élutions isocratiques et par gradient sur des colonnes garnies de phases au divinylbenzène polystyrène aminomodifiées en utilisant $\mathrm{NaOH}$ à $0,1 \mathrm{~N}$ comme éluant. 
Un détecteur ampérométrique pulsé a servi à mettre les composés en évidence après addition post-colonne d'une solution $1 \mathrm{~N}$ de $\mathrm{NaOH}$. Vingt-deux et vingtquatre hydrates de carbone sur vingt-cing ont ęté respectivement séparés par élution isocratique et par gradient. On a identifié quelques mono et disacchatides dans les échantillons de tabac à partir de leurs durées de rétention; le glucose, le fructose, l'inositol et le saccharose ont été dosés dans différentes variétés de tabac.

\section{INTRODUCTION}

Carbohydrates make up a large portion of the leaf of many tobacco varieties, both in the free or in the combined state, and are of great interest because of their relationship to leaf quality and smoke flavour. Many papers have been published concerning the analysis of low molecular weight carbohydrates in tobacco leaf and in cigarette filler (1).

Some authors determined the total reducing sugars with colorimetric methods, others described gas chromatographic procedures using the trimethylsilyl derivatives or estimate the individual compounds by paper and thin-layer chromatography (2-6).

Many authors use the high-performance liquid chromatography for rapid characterization of tobacco sugars $(7-16)$. The purpose of this work is to find the best conditions for detecting and determining as large a number as possible of both reducing and non reducing low molecular weight carbohydrates present in standard mixtures and to apply such conditions to the analyses of tobacco leaf and cigarette filler by the aid of the high-performance ion chromatography with pulsed amperometric detection.

\section{EXPERIMENTAL}

\section{Reagents}

The twenty-five carbohydrates (Merck, grade for biochemistry) reported in Table 1 were used without further purification to prepare the standard solutions, using distilled water, purified in an Elgastat (ELGASTAT UHR system, by Elga) system (1).

These solutions were kept at $4{ }^{\circ} \mathrm{C}$ and were found to be stable for at least 15 days. Solutions of $0.1 \mathrm{~N}$ and $1.0 \mathrm{~N} \mathrm{NaOH}$ (Merck or Fluka reagent grade) were used. All eluent solutions were prepared by bubbling helium through the water to prevent carbon dioxide contamination, and were kept under a blanket of helium during elution.

\section{APPARATUS AND PROCEDURES}

A Dionex Bio-LC chromatograph equipped with:

- a gradient pump module, operating up to 4000 p.s.i.;

- a Dionex eluent degas module with eluent container set;

- a pulsed amperometric detector (PAD-2) containing a working gold electrode;

- a Dionex sample injection valve with a $50 \mu \mathrm{l}$ sample loop;

- a Dionex DOP-1 post column pumping system;

- On-guard RP filters;

- HPIC-AS6 column with amino modified polystyrene-divinylbenzene phase $(250 \times 4 \mathrm{~mm}, 10 \mu \mathrm{m}$ particle size bed) protected by a guard column HPIC-AG6 (70 × $4 \mathrm{~mm})$;

- HPIC-AS6A column (150 x $4 \mathrm{~mm})$ with amino modified polystyrene-divinylbenzene phase, $5 \mu \mathrm{m}$ particle size bed, protected by a guard column HPIC-AG6A ( $50 \times 4 \mathrm{~mm}$ );

- a Varian 1200 recorder.

\section{OPERATING CONDITIONS}

Temperature: room-temperature in the range 18 . $23^{\circ} \mathrm{C}$

PAD operating parameters: $\quad \mathrm{E}_{1}=0.10 \mathrm{~V}$

$E_{2}=0.60 \mathrm{~V}$

$\mathrm{E}_{3}=-0.80 \mathrm{~V}$

$\mathrm{T}_{1}=\mathrm{T}_{2}=\mathrm{T}_{3}=300 \mathrm{msec}$

Output range: $10 \mathrm{\mu A}$; chart speed: $1.0 \mathrm{~cm} / \mathrm{min}$

For isocratic elutions:

Flow rate: $\quad 0.6 \mathrm{ml} / \mathrm{min}$

Eluent: $\quad \mathrm{NaOH} 0.1 \mathrm{~N}$

For gradient elutions:

Flow rate: $\quad 1.0 \mathrm{mi} / \mathrm{min}$;

Gradient program:

\begin{tabular}{c|c|c}
$\begin{array}{c}\text { Time } \\
(\text { min })\end{array}$ & $\begin{array}{c}\text { Water } \\
(\%)\end{array}$ & $\begin{array}{c}\mathrm{NaOH}(0.2 \mathrm{~N}) \\
(\%)\end{array}$ \\
\hline 0 & 100 & 0 \\
5 & 100 & 0 \\
8 & 85 & 15 \\
15 & 85 & 15 \\
45 & 10 & 90 \\
50 & 10 & 90 \\
51 & 100 & 0
\end{tabular}

Post column reagent: $\mathrm{NaOH} 1 \mathrm{~N}$ at flow rate of 1 $\mathrm{ml} / \mathrm{min}$. 
Table 1.

Chromatographic data of 25 carbohydrates in the HPIC system.

\begin{tabular}{|c|c|c|c|c|}
\hline Peak Numbers & Sugars & ${ }^{4} t_{B}(\min )$ & $a^{b}$ & ${ }^{\circ} \mathrm{RRT}$ (min) \\
\hline 1 & Inositol & 1.71 & 0.10 & 0.19 \\
\hline 2 & Xylitol & 1.89 & 0.22 & 0.21 \\
\hline 3 & Sorbitol & 2.23 & 0.44 & 0.26 \\
\hline 4 & Mannitol & 2.45 & 0.59 & 0.30 \\
\hline 5 & Trehalose & 2.62 & 0.70 & 0.33 \\
\hline 6 & Fucose & 2.62 & 0.70 & 0.58 \\
\hline 7 & 2-Deoxy-D-Ribose & 2.89 & 0.87 & 0.69 \\
\hline 8 & 2-Deoxy=D-Galactose & 3.04 & 0.97 & 0.77 \\
\hline 9 & Rhamnose & 3.20 & 1.07 & 1.00 \\
\hline 10 & 2-Deoxy-D-Glucose & 3.56 & 1.30 & 1.13 \\
\hline 11 & Arabinose & 3.56 & 1.30 & 1.15 \\
\hline 12 & Galactose & 3.98 & 1.58 & 1.29 \\
\hline 13 & Lyxose & 4.23 & 1.73 & 1.39 \\
\hline 14 & Glucose & 4.23 & 1.73 & 1.44 \\
\hline 15 & Xylose & 4.30 & 1.78 & 1.51 \\
\hline 16 & Fructose & 4.63 & 1.99 & 1.55 \\
\hline 17 & Allose & 4.99 & 2.23 & 1.64 \\
\hline 18 & Ribose & 5.17 & 2.34 & 1.74 \\
\hline 19 & Melibiose & 5.41 & 2.50 & 1.74 \\
\hline 20 & Sucrose & 6.77 & 3.38 & 1.96 \\
\hline 21 & Lactose & 7.21 & 3.66 & 2.32 \\
\hline 22 & Cellobiose & 9.67 & 5.26 & 2.72 \\
\hline 23 & Gentiobiose & 10.18 & 5.59 & 2.80 \\
\hline 24 & Raffinose & 11.60 & 6.51 & 2.89 \\
\hline 25 & Maltose & 15.99 & 9.34 & 3.55 \\
\hline
\end{tabular}

- $\quad t_{k}=$ Retention times in Isocratic elution

${ }^{t_{R}} t_{R}=\left(t_{c}-t_{0}\right) / t_{0}$, where $t_{c}=$ retention times of carbohydrates and $t_{0}=$ retention time of eluent in isocratic elution

'RRT = retention times relative to inamnose in gradient elution.

\section{ANALYSES OF TOBACCO}

The tobacco leaves or the cigarette filler were ground and amounts of $100 \mathrm{mg}$ of tobacco powder were weighed. The samples were shaken twice with $50 \mathrm{ml}$ of distilled and purified water and both extracts were combined and filtered. The solution was then injected through an On-Guard RP filter into the sample injection valve of the chromatograph using a $50 \mu \mathrm{l}$ sample loop. Samples were analyzed not later than eight hours after the extraction, because the solutions of carbohydrates extracted from tobacco were unstable.

\section{RESULTS}

The chromatographic data of 25 carbohydrates are given in Table 1 . The retention times and the values of $t_{R}^{\prime}$ were obtained under isocratic conditions. The retencion times under gradient conditions are relative to thamnose. Twenty-two out of twenty-five carbohydrates were separated by isocratic elution and twenty- four out of twenty-five by gradient elution. For detection and identification a pulsed amperometric detector has been used. The chromatograms are shown respectively in Figures 1 and 2. Several tobacco leaf samples, obtained from different varieties, were analyzed. Typical chromatograms of some main varieties are shown in Figures 3-6. Some mono and disaccharides were identified from their retention times; the most important were inositol, glucose, fructose, sucrose and galactose, the latter only in samples of Burley.

Some quantitative determinations of glucose, fructose, inositol and sucrose were carried out for samples of oriental tobaccos, bright and Kentucky. The range of concentrations are given in Table 2.

In order to check the range of linearity of the detector response a linear calibration graph was obtained for each of the four carbohydrates by plotting peak areas $v$ concentrations (range 1-100 $\mathrm{\mu g} / \mathrm{ml}$ ) with correlation coefficients in the range $0.99939-0.99996$. The linearity of the responses was confirmed using thamnose as internal standard. Linear calibration graphs were obtained by plotting the ratio $A_{c} / A_{t}$ vs concentrations, 


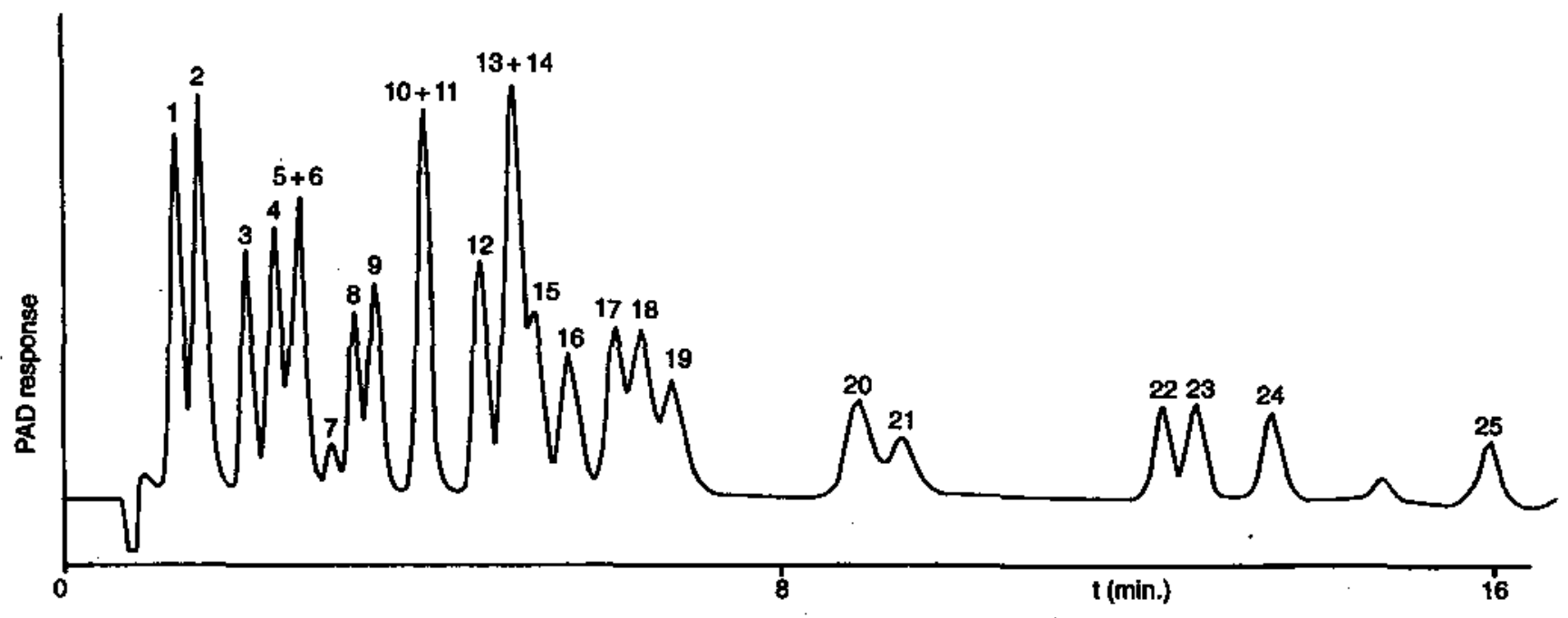

Flgure 1.

Chromatogram of a standard mlxture of carbohydrates separated by lsocratic elution. The numbers of the peaks correspond to the compounds reported in Table 1.

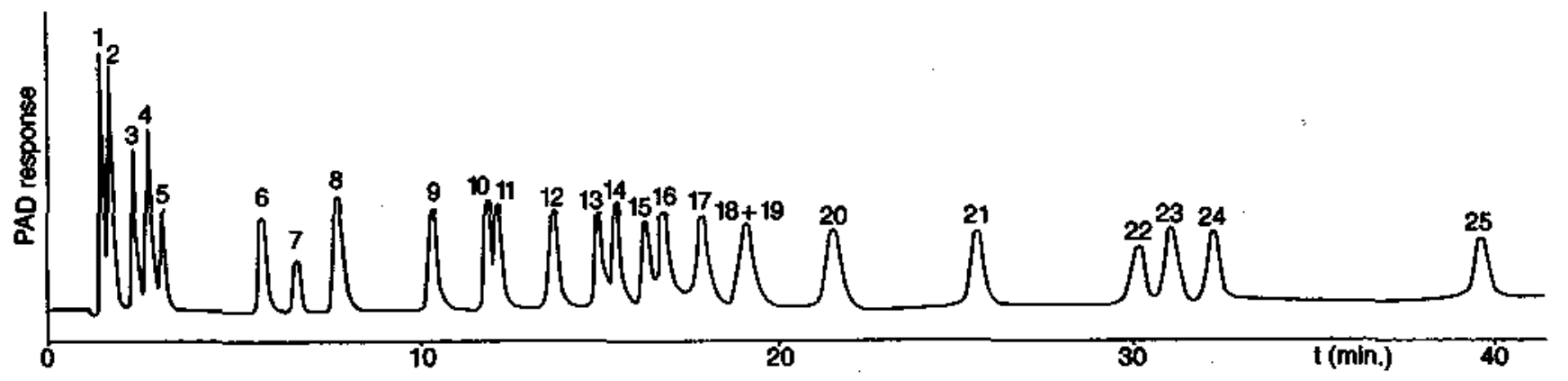

Figure 2.

Chromatogram of a standard mlxture of carbohydrates separated by gradlent elution. The numbers of the peaks correspond to the compounds reported in Table 1. 


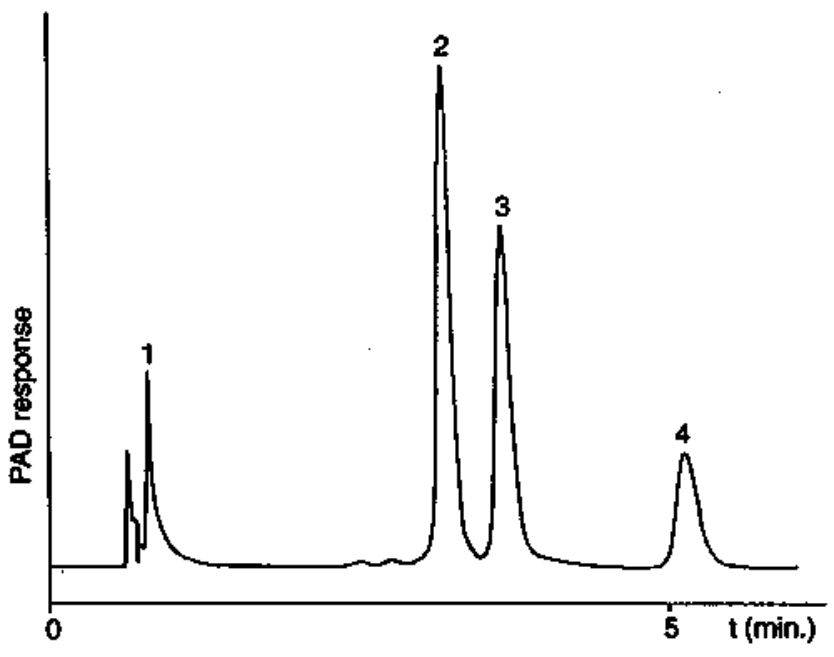

Figure 3.

Bright - Isocratic elution. Meter scale: $10 \mu \mathrm{A}$.

$\begin{array}{lllll}1 & : & \text { Inositol } & 2 & \text { Glucose } \\ 3 & : & \text { Fructose } & 4: & \text { Sucrose }\end{array}$

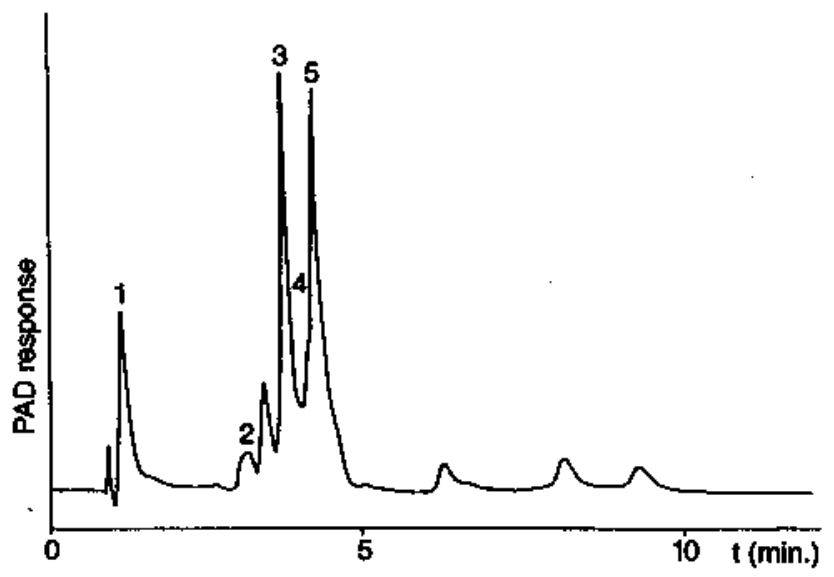

Flgure 4.

Xanty - Isocratic elution. Meter scale: $10 \mu \mathrm{A}$.

$\begin{array}{lllll}1 & : & \text { Inositol } & 2 & \text { Arabinose } \\ 3 & : & \text { Glucose } & 4: & \text { Xylose } \\ 5 & : & \text { Fructose } & & \end{array}$

were $A_{c}$ is the peak area of each carbohydrace and $A_{t}$ is the peak area of rhamnose.

The correlation coefficients were in the range 0.99984

- 0.99999.

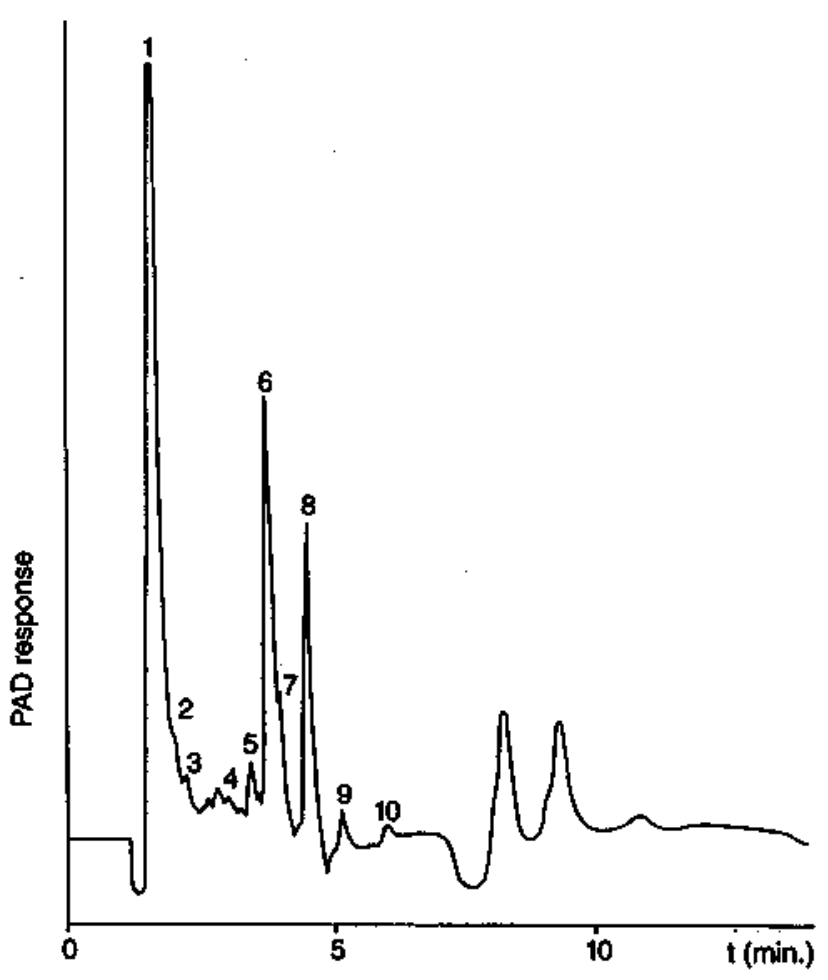

Figure 5.

Kentucky - Isocratic elution. Meter scale: $3 \mu \mathrm{A}$.

$\begin{array}{llllll}1 & : & \text { Inositol } & 2 & : & \text { Sorbitol } \\ 3 & : & \text { Mannitol } & 4 & : & \text { Rhamnose } \\ 5 & : & \text { Arabinose } & 6 & : & \text { Glucose } \\ 7 & : & \text { Xylose } & 8 & : & \text { Fructose } \\ 9 & : & \text { Mellblose } & 10: & \text { Sucrose }\end{array}$

\section{DISCUSSION AND CONCLUSIONS}

Carbohydrates behave as weak acids with a pKa in the range $12-14$. They are present in the anionic form in solutions with a $\mathrm{pH}>12$ and can be retained and separated on anion exchange columns. Carbohydrates are also easily oxidized on the surface of noble metal electrodes such as gold (17-22).

The pulsed amperometric detector uses a multistep potential wave form of three different voltages, each applied for a few hundreds milliseconds, resulting in alternating anodic and cathodic polarizations. The first positive voltage allows, through an oxidating reaction, the amperometric detection of the $-\mathrm{CH}_{2} \mathrm{OH}$ functions of carbohydrates; the second higher positive potential cleans electrochemically the electrode surface, while the third negative voltage reduces gold oxide back to gold. 


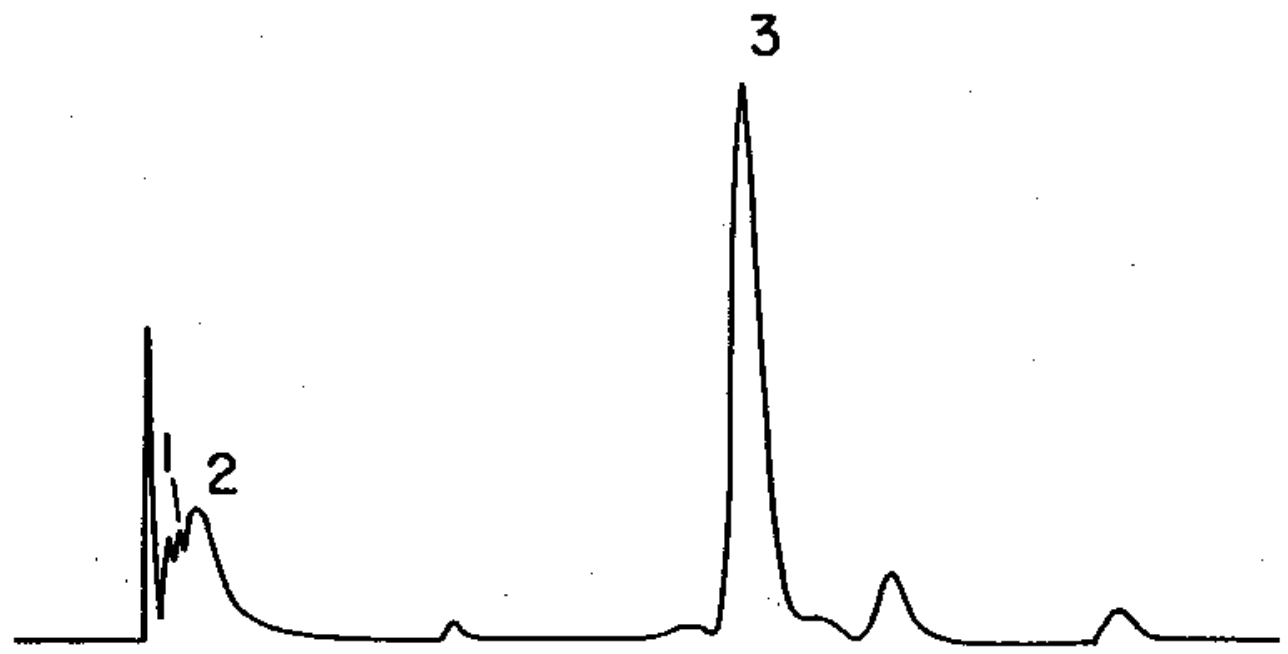

Figure 6.

Burley - Isocratic elution. Meter scale: $10 \mu \mathrm{A}$.

1 : Inositol 2 : Xylitol 3 : Galactose

With such a detector only molecules having oxidizable functional groups can be detected and therefore only compounds with amino or sulfide groups can interfere, while carboxylic acids and most of the inorganic species do not. The molecules containing carbonyl functions are not oxidized at the operating conditions followed in the present work $(23,24)$.

Only some of them, such as formaldehyde and acetaldehyde, are detected when they are present in very high concentrations, $100 \mu \mathrm{g} / \mathrm{ml}$ and $200 \mu \mathrm{g} / \mathrm{ml}$ respectively, giving however only low signals.

Furthermore, the anion-exchange chromatography allows a good separation of a large number of carbohydrates, from monosaccharides to low molecular-weight polysaccharides, while non-ionic and basic compounds, even if oxidizable, are not retained and elute in the void volume without any interference. It is still possible to achieve high sensitivity: amounts in the range $0.02-1.00 \mu \mathrm{g} / \mathrm{ml}$ were easily detected, while the detection limits for the most important sugars present in tobacco samples were in the range 5-25 ppm (Table 3). In the gradient elutions the sensitivity is increased by adding a more concentrated solution of sodium hydroxide $(1.0 \mathrm{~N})$ after the analytical column, thereby keeping the $\mathrm{pH}$ in the detector cell relatively constant and achieving also a lower drift of the baseline. Carbohydrate degradation in high $\mathrm{pH}$ solutions was not observed: these reactions are slow on the time scale of chromatography employed.

Table 2.

Range of concentrations of some sugars detected in tobacco varietles.

\begin{tabular}{l|c|c|c|c|c}
\hline Varieties & $\begin{array}{c}\text { Number of } \\
\text { Samples }\end{array}$ & $\begin{array}{c}\text { Inositol } \\
(\%)\end{array}$ & $\begin{array}{c}\text { Glucose } \\
(\%)\end{array}$ & $\begin{array}{c}\text { Fructose } \\
(\%)\end{array}$ & $\begin{array}{c}\text { Sucrose } \\
(\%)\end{array}$ \\
\hline $\begin{array}{l}\text { Oriental } \\
\text { Bright }\end{array}$ & 38 & $0.69+1.70$ & $2.0+9.5$ & $2.4+8.5$ & traces \\
Kentucky & 84 & $0.72+1.60$ & $3.2+17.0$ & $4.9+12.2$ & $0.5+6.0$ \\
traces \\
\hline
\end{tabular}


Table 3.

Detection limits for some sugars In tobacco.

\begin{tabular}{|c|c|c|c|}
\hline $\begin{array}{c}\text { Peak } \\
\text { Numbers }\end{array}$ & Sugars & $\begin{array}{c}S \\
\mu \mathrm{g} / \mathrm{ml}\end{array}$ & $\begin{array}{l}\text { D.L. } \\
\text { ppm }\end{array}$ \\
\hline 1 & Inositol & 0.02 & 5 \\
\hline 2 & Xyditol & 0.02 & \\
\hline 3 & Sorbitol & 0.04 & \\
\hline 4 & Mannitol & 0.03 & \\
\hline 5 & Trehalose & 0.07 & \\
\hline 6 & Fucose & 0.06 & \\
\hline 7 & 2-Deoxy-D-Ribose & 1.00 & \\
\hline 8 & 2-Deoxy-D-Galactose & 0.05 & \\
\hline 9 & Rhamnose & 0.05 & \\
\hline 10 & 2-Deoxy-D-Glucose & 0.06 & \\
\hline 11 & Arabinose & 0.06 & 10 \\
\hline 12 & Galactose & 0.05 & 10 \\
\hline 13 & Lyxose & 0.06 & \\
\hline 14 & Glucose & 0.05 & 10 \\
\hline 15 & Xylose & 0.06 & \\
\hline 16 & Fructose & 0.05 & 10 \\
\hline 17 & Allose & 0.05 & \\
\hline 18 & Ribose & 0.10 & \\
\hline 19 & Melibiose & 0.10 & \\
\hline 20 & Sucrose & 0.10 & 25 \\
\hline 21 & Lactose & 0.10 & \\
\hline 22 & Cellobiose & 0.15 & \\
\hline 23 & Gentiobiose & 0.10 & \\
\hline 24 & Raffinose & 0.10 & \\
\hline 25 & Maltose & 0.15 & \\
\hline
\end{tabular}

$\mathbf{S}=$ sensitivity

D.L. = Detection limits

Anion-exchange liquid chromatography with pulsed amperometric detection proved to be an efficient technique for the separation, identification and quantitative determination of low molecular weight carbohydrates in tobacco leaves and in cigarette filler.

This system represents a method of choice, providing many advantages such as specificity, selectivity, sensitivity and reliability, which can be used when it is necessary to determine the amounts of the individual reducing and non reducing sugars.

\section{REFERENCES}

1. Oakley, E.T.: Ouantitative determination of sucrose and fructose in tobacco and filter; Tob. Sci. 17 (1973) 99-101.

2. Tate, M.E.: Thin layer chromatography of carbohydrates acetates; Can. J. Chem. 40 (1962) 1043-1048.
3. Siddiqui, I.R. and N. Rosa: Low molecular weight carbohydrates of tobacco; Tob. Sci. 27 (1983) 130-134.

4. Genim, N. and S. Peeva: Identification and determination of soluble carbohydrates in tobacco by gas-chromatography; C. A. 95 (1981) 165610y.

5. Ivetson, J.L. and M.P. Bueno: Evaluation of high pressure liquid chromatography for quantitacive determination of sugars in food; J. Assoc. Off. Anal. Chem. 64 (1981) 139-143.

6. Ryan, W.S. Jr.: Neutral sugar analysis of tobacco cell wall fractions; Beitt. Tabak. Int. 12 (1984) 105-111.

7. Battard, J.C. and C. Chauvett: Rapid characterization of tobacco sugars by high performance liquid chromatography; Ann. Tab. 1 (1978) 16.

8. Posch, B.: High performance liquid chromatography of sugar mixtures containing xylose and arabinose on primary amino-bonded phases; J. Chromatogr. 253 (1982) 49-54.

9. Wentz, F. E., A.D. Marcy and M.J. Gray: Analysis of wood sugars in pulp and paper industry samples by HPLC; J. Chromatogr. Sci. 20 (1982) 349-352.

10. Lenherr, A., T.J. Mabry and M.R. Gretz: Differentiation between glucose, mannose, allose and galactose in plant glucosides by high performance liquid chromatography analysis; J. Chromatogr. 388 (1987) 455-458.

11. Buszewski, B. and R. Lodkowski: Isolation and determination of sugars in nicotiana tabacum on aminopropyl chemically bonded phase using SPE and HPLC; J. Liquid Chromatogr. 14 (1991) 1185-1201.

12. Verzele, M., G. Simoens and F. Van Damme: A critical review of some liquid chromatographic systems for the separation of sugars; Chromatographia 23 (1987) 292-300.

13. Taverna, M., A.E. Baillet and D. Baylocq-Ferrier: Identification of monosaccharides by high performance liquid chromatography using methanolysis and a light-scattering detector; J. Chromatogr. 514 (1990) 70-79.

14. Yang M.T., L.P. Milligan and G.W. Mathison: Improved sugar separation by high performance liquid chromatogrphy using porous microparticle catbohydrate columns; J. Chromatogr. 209 (1981) 316-322.

15. Verhaar L.A. and B.F.M. Kuster: Liquid chromatography of sugars on silica-based stationary phases; J. Chromatogr. 220 (1981) 313-328.

16. Batley, M., J.W. Redmond and A.Tseng: Sensitive analysis of aldose sugars by reversed phase High performance liquid chromatography; J. Chromatogr. 253 (1982) 124-128. 
17. Martens, D.A. and W.T. Frankerberger jr.: Determination of saccharides by high performance anion-exchange chromatography with pulsed ampetometric detector; Chromatographia 29 (1990) 7-12.

18. Honda, S., S. SuZuki and K.Kakehi: Improved analysis of aldose anomers by high performance liquid chromatography on cation-exchange columns; J. Chromatogr. 291 (1984) 317-325.

19. Quigley, M.E. and H.N.Englyst: Determination of neutral sugars and hexosamines by high performance liquid chromatography with pulsed amperometric detector; Analyst 117 (1992) 1715-1718.

20. Johnson, D.C. and W.R. LaCourse: Liquid chromatography with pulsed amperometric electrochemical detection at gold and platinum electrodes; Anal.Chem. 62 (1990) 598-597.

21. Welch, L.E., D.A. Mead jr. and D.C. Johnson: A comparison of pulsed amperometric detection and conducivity detection for carbohydrates; Analytica Chim. Acta 204 (1988) 323-327.

22. Haginaka, J. and T. Nomura: Liquid chromatographic determination of carbohydrates with pulsed amperometric detection and a membrane reactor; J. Chromatogr. 447 (1988) 268-271.
23. LaCourse, W.R., D.A. Mead and D.C.Johnson: Anion-exchange separation of carbohydrates with pulsed amperometric detection using a $\mathrm{pH}$-selective reference electrode; Anal. Chem. 62 (1990) 220-224.

24. Larew, L.A. and D.C. Johnson: Concentration dependence of the mechanisms of glucose oxidation at gold electrodes in alkaline media; J. Electroanal. Chem. 262 (1989) 167. 